\title{
Muslim Learners in English schools: a challenge for school leaders
}

\begin{abstract}
Faith identity is emerging as significant for Muslim students in the post $9 / 11$ scenario, with implications for their education and wider social cohesion. This poses challenges to school leaders, raising issues not only linked to student achievement and performance, but also with regard to students' identity constructions and their educational engagement. The paper draws on data collected from a small number of teachers and Muslim students from two secondary schools in England, looking at how Muslim students experience their identity in the school context and with what implications for their educational engagement. It also discusses the challenges for educational leaders/teachers in managing Muslimness' on educational sites. The data indicates that the increasing engagement with faith identity can be a response to experiences of discrimination, marginalisation and negative media. The paper highlights the need for communication and understanding across differences, underpinned by an equally pressing need for the recognition of religious and cultural diversity.
\end{abstract}

Institutional demographics have great significance for school leaders and teachers because these impact on daily practices in schools, as well as on the relevant policy. The management contexts of schools in England, particularly in the urban areas have been undergoing deep and sensitive changes in the wake of emigration, international mobility and globalisation. These emerging multi-ethnic (multi-cultural/multi-faith!) schools have population structures which pose challenges to school leaders, demanding wider knowledge, understanding and sensitivity.

This paper focuses on Muslim learners in English schools, and debates the challenges of managing Muslimness, particularly in the post 9/11, 7/7 scenario. There are 1.6 million Muslims in Britain and 33.8\% are aged 0-15 years (National Statistics, 2001), who fall within the compulsory education age. Muslim students in British schools are more than half a million (Anwar and Bakhsh, 2002, p. 2, 3), and unlike some other faith groups, Muslims tend to highlight their religious identity (Brah, 1996; Jacobson, 1998; Modood, 2005; Shah 2006a), which can be problematic in a proclaimed secular context. In addition to that, in the British context, multiple social, economic, strategic, historical and political factors further add to the complexities of interface.

The paper draws on a wide range of international literature to engage with relevant debates. It avails direct data collected from a small study to discuss the perceptions of British minority ethnic Muslim students and their teachers/leaders with regard to 
Muslimness, and its implications for schooling. Muslims in Britain have emerged as a politically visible community specifically in the post-Satanic Verses context. The Muslim/non-Muslim divide is traditionally underpinned by numerous factors including historical and political legacies such as the Muslims in Spain/Jerusalem, the crusades, the Western Imperialism (Ahmed, 1992). More recently the plight of Muslims in Palestine, Kashmir and other parts of the world, the role of West (particularly of America) in the Gulf war, Iran/Iraq war and Afghan Jihad against Russia, as well as a wider religious resurgence, the perceived clash of civilisations, the economic war, the Middle-East oil and the struggle for control over international resources have added to the tensions (Ahmed, 1992; Esposito, 1999; 2002). In this backdrop, the stand taken by the West over the Satanic Verses issue flared emotions to a higher pitch. The Muslims perceived this as an attack against their core belief that no one should be free to insult and malign Muslims by disparaging the honour of the Prophet. The protests against Rushdie and burning of Satanic Verses fuelled the drive to be recognised and respected as Muslims (Ahmed AS, 2003; Kepel, 2003). Later international events such as the Al-Qaeda factor, the 9/11, invasions of Afghanistan and Iraq, and more recently the stand taken by the West on publishing of the Prophet's cartoons and Knighting of Rushdie have further left their marks both on in-group and out-group identity formations of young Muslims, posing challenges to school leaders and teachers.

The political, social, economic and educational are not discrete zones. The wider global developments influence educational sites, posing new challenges to educational leaders and teachers, as well as to the policy makers. The Muslim learners have become the focus of policy attention due to political opinions suggesting that pockets of Muslim youth are harbouring extreme Islamic views which are partly manifested in their resentment towards the British way of life. Muslims' insistence on dress code, halal food, and prayer space were some of the early demands (Parker-Jenkins, 1995) sending signals to be acknowledged and respected as Muslim. Certain policy responses conceded to these demands in a very limited way, subject to context and resources. However, these measures are now perceived as insufficient, and complaints of the British education system's failure to attend to the needs of Muslims have continued (MCB, 2007). 
These concerns are exacerbated by the issue of educational achievement of Muslim learners. Studies and surveys have highlighted that Muslim learners, educated through the British state system are suffering academically, culturally and linguistically as a high proportion of Muslim learners are leaving British schools with low grades or no qualification (Abbas, 2006; Ahmad, 2002; Archer, 2003; Coles, 2004; DFES, 2004; Haque, 2000). Furthermore, they are exposed to the expressions of racism, Islamophobia and bullying (Bagguley and Hussain, 2007; Richardson and Wood, 2004; Tyrer and Ahmad, 2006). Many schools are either not fully aware or not doing enough to combat racist attitudes amongst pupils to tackle racism and promote race relations, for either lack of resources or other pressures. In this context of discrimination (Parekh, 2000), policy directives such as equal opportunities agenda, Race Relations (Amendment) Act, Widening Participation, Every Child Matters Agenda, or Building Schools for Future cannot fully respond to the specific needs of Muslims. An important question here is how do Muslim learners experience their identity in schools and with what implications for their schooling? Secondly, are there any challenges for school leaders/teachers in managing Muslimness particularly with regard to achievement and inclusion?

The data on achievement/underachievement is collected by ethnicity and not by faith which makes it hard to explore link between achievement and faith identity. However, as certain ethnic groups in Britain such as Pakistanis, Bangladeshis, Somalis, and others are predominantly of Muslim faith, relevant ethnic data is often availed as reflective of faith group which has limitations ${ }^{\mathrm{i}}$. This paper draws on data collected from two state comprehensive schools with explicit reference to faith, to debate the issues raised above. The study was carried out in 2006 as a pilot to generate views and discussions underpinning a proposed research project.

The two schools selected for this study represented two large Muslim communities in Britain, Pakistanis/Kashmiris and Bangladeshis (National Statistics, 2001). Many research studies emphasise underachievement of students from these two communities, voicing concern and apprehension (Abbas, 2004, 2006; Anwar and Bakhsh, 2002; Modood, 2003), which justified choosing these schools purposively to explore the issues. The participating students were from different year groups, both males and females, and 
were all Muslims, while teachers were Muslims and non-Muslims, males and females. The sample included twelve students and 5 teachers (3 Muslim and two non-Muslim) in school A, and ten students and six teachers (2 Muslim and 4 non-Muslim) in school B. The focus was to investigate how Muslimness was conceptualised and practised, and with what implications for the school leaders and for the learners and their schooling.

The data was collected through interviewing which was more like focused interaction structured around issues of Muslim identity, how it is experienced (by students) or managed (by leaders/teachers), and associated challenges for leaders/teachers. The intention was to provide the participants a flexibility to 'pursue a more conversational style of interview that may see questions answered in an order natural to the flow of conversation. ... start with a few defined questions but be ready to pursue any interesting tangents that may develop' (O'Leary, 2005, p.164). The participating students and teachers talked about their experiences of Muslimness, and its implications for inclusion/achievement, making suggestions for policy and practice.

\section{Muslim Students and Identity}

The drive towards an overarching Muslim identity is international in dimensions including countries like China (Alles, 2003; Chiang, 2001; Djao, 2004), America (Afridi, 2001), Britain (Basit, 1997; Jacobson, 1998; Hopkins and Kahani-Hopkins, 2004), France (Le Breton 1999; Limage, 2000; Tlemçani, 1997), and many others (Haddad, 2002; Kepel, 1997; 2003; Modood, 2004). The concept of Islamic Ummah (community) provides the basis for this super-ordinate identity to an otherwise hugely diversely community (Shah, 2006a; see also Lewis, 1994; Mandaville, 2001; Modood, 2004). The concept of Ummah has gained further prominence in the recent times due to diverse global developments mentioned above, leading to stronger affiliations with faith identity (Ahmed AS, 2003; Esposito, 1999; 2002; Hopkins and Kahani-Hopkins, 2004; Kepel, 1997, 2003). This heightened awareness of religious identity among Muslims is emerging as a new 'force of resistance' (Hall, 1992). Modood (2005) explains it as: 
a politics of projecting identities in order to challenge racism and existing power relations; of seeking not just toleration for ethnic difference, but also public acknowledgement, resources and representation (p.286).

Projection of faith identity among Muslim youth signals a challenge to racism and a struggle to establish personal identities. Explorations into Muslim students' perceptions of their identity in educational contexts affirm that their primary descriptor of identity is 'Muslimness' (Jacobson, 1998). Admittedly, there is considerable fragmentation within Muslim community, however:

A strong sense of identity that has established roots and finds support in a much broader community ... can be a wonderful resource for combating prejudice, stereotyping and maltreatment. (Merry, 2007, p.97)

Giddens (1993) posits that a self-identity has to be created and more or less continually reordered against the backdrop of shifting experiences of day-to-day life. The perceived targeting of Islam and Muslims in recent history has encouraged in-group cohesion at a political level, driving them towards a concept of Muslimness which appeared to offer a sense of security and belonging, in opposition to the feelings of insecurity and otherness. The dynamics involved in the construction of 'Muslimness' are generated by internal images and discourses, and perceived external threats (Brasted, 2005; Shah, 2006a). There is huge literature on identity in sociology, social psychology and feminist theory (Bhabha, 1994; Brah, 1996; Giddens, 1993; Hall, 1996), but recognition of religion as a category of influence for identity construction is not a fully explored phenomenon. The recent religious resurgence invites to engage with identity constructions and projections with higher understanding and sensitivity to work towards societal cohesion and 'cultural coherence' at all levels.

Muslimness is one of the hybridic identities, reinforcing the argument that identities are multiple and fluid (Vincent 2003) and keep changing as the nature of political and economic relationships changes between groups, communities and countries. The contending perceptions of Muslimness - a valued self-definition for the Muslims and a 
perceived threat by the wider society - not only pose a challenge to practices in schools, but also according to Werbner (2000), 'British Muslim transnational loyalties have challenged the national polity' (p. 309). It is highly important in a multiethnic society to investigate the forces driving towards such identity formations, and their impact on the individuals and the society as a whole (Griffiths and Troyna, 1995). The ways in which Muslim students understand and interpret their identity and their experiences of school, and how these are interpreted and managed by educational leaders/teachers are significant for the debates on achievement, integration and cohesion. Responding to how do they define their identity or see themselves, the participating students and Muslim members of staff invariably defined themselves as 'Muslim first'. Nonetheless, they generally explicated the response by mentioning their ethnic and/or British identity, often in that order:

I'm Muslim before anything else. I would say I am a British, I would also say I am a Pakistani but it's less important than Muslim.

Although in each of the case schools the majority of Muslim participants belonged to one ethnic group (either Bangladeshi or Pakistani), there were some variations. In one school there was one participant originally from Iran and another from Algeria. In the second school three Muslim participants originated respectively from Bosnia, Iraq, and Tunisia. They had different parent languages, belonged to diverse sub-cultures, and dressed different. Dress variation was more obvious among Muslim girls whose dresses ranged from short sleeveless skirt to loose full body dress along with a scarf tied round the head. However, they all associated themselves primarily with Muslim identity:

I'm not that religious but I'm Muslim

Another participant argued:

'Muslims are one body ... religious element binds us all'.

This seems to be a level where heterogeneity of the faith group is transcended by the concept of Muslim Ummah (Al-Ahsan, 1992). The perceived Muslim/non-Muslim 
conflict appears to drive them or lure them to identify with Muslimness, as reflected in many responses. One Muslim teacher commented while mentioning Iraq war:

We are all Muslims and we are like one body --- one part hurts, we all suffer. Then it comes down to a human level.

Is this identification with Muslimness in opposition to what is perceived as global antiIslam or anti-Muslim phenomenon? The indications are that identity formation is an immensely sensitive and complex arena, which may lend to political exploitation. Masses get caught in the tug of war and are forced to take sides. Kabbani comments in postSatanic-Verses situation:

We were caught between two tyrannies: Khomeini's impossible death sentence against a writer (fallible or foolish though he may have been) and the harsh "liberal" fatwa against our religious identity, with its blanket dismissal of us as alien, barbaric. Such was the polarisation, that even those who had hardly perceived of themselves as "Muslim" before, except in family ritual or personal reference, were suddenly forced to stand up and be counted as "warriors" for subtlety in either side's position. (2002, p. 1)

In the present scenario, the perception among the Muslims, particularly among the youth, of being 'targeted' (Ahmed AS, 2003; Ahmed ST, 2003a; Esposito, 2002; Hagopian, 2004), special registration, police raids/interrogations, profiling of Muslims, Shooting by police of a Brazilian who looked Asian (BBC, 2005) and 'stop and search' practices targeting particular Muslim groups (MPA, 2004) have left them feeling insecure and even paranoid. The Muslim participants in the London school also referred to police raid of June 2, 2006 in Forest Gate (East London), pointing out that although the charges were dropped later (BBC, 2006), the effects on race relations and social cohesion might not be short-living:

After the police raid lots of people in East London do hate them. Police wouldn't go after white people like this if allegations of bomb-making were made. 
Werbner argues that 'exclusion, silencing, any act of discrimination is an act of violence', emphasising that 'violence begets violence, and violence need not be physical' (1997, p. 228). Being imagined and created by media and masses as 'potential terror suspects' (Ahmed ST, 2003b, Hagopian, 2004, Hardy, 2005) and being at the receiving end of 'institutional racism (Macpherson, 1999; Ahmad, 2006) has generated significant insecurity among Muslim students, with uncharted consequences for their learning, inclusion and commitment to the wider society. These processes and practices are dividing the society and undermining Muslims' sense of belongingness, driving them in search of personal identities. Sen (2006) argues that most of the conflicts in the contemporary world arise from individuals' notions of who they are, and which group/s they belong to in opposition to others. Equally significant are the factors and forces that drive individuals towards these group identities. A study commissioned by CRE (2005) found that:

Religion was a dominant source of identification for Muslim participants. It would seem that the emotional significance attached to Islam has grown in strength over the recent past, as issues in the public domain (such as the conflict in Afghanistan, the war in Iraq, and the terrorist attacks in New York, Washington and London) have been construed as antagonistic relations specifically between Muslims and Christians. (p. 38)

The enhanced desire among Muslim youth to emphasise their faith identity signifies their dissatisfaction with the discrimination and marginalisation experienced as minority ethnic Muslims in a politicised anti-Muslim climate. There is no doubt that the religious identity is subject to harsh political opposition, but it also provides a power discourse to operate in. To a young teen-ager's self-esteem, an association with a 'powerful' cosmic identity could be more appealing as compared to a targeted BME identity. The need is to analyse the issues and to search for answers.

\section{Experiencing Muslimness in Schools}


It is important to explore how students experience 'Muslimness' at a time of potential polarisation, and how these experiences contribute to their identity formations and schooling. Many studies (Bagguley and Hussain, 2007; Richardson and Wood, 2004, Tyrer and Ahmad, 2006) highlight religious discrimination and racism experienced by Muslim students in educational institutions, with specific references to experiences of Islamophobia (Richardson, 2004; Driel, 2004). Literature and archives abounds with records of racist media constructions of Muslims 'in very derogatory and vilifying ways' (Vertovec, 2002). These images and constructions influence Muslims' participation in all fields of mainstream activities including education:

There was a newspaper article about racism. It asked a hundred white people about it - and most hated was Asians, Muslims. That makes me realise I'm walking around now and people are looking at me in a different way. (Parekh, 2000 quoted in Richardson and Miles, 2003, p. 13)

Hall argues that racism 'operates by constructing impassable symbolic boundaries between racially constructed categories' $(1992$, p. 255). The media, in its own interests and traditions, plays a strong role in spreading and perpetuating these divides, creating an atmosphere of mistrust and resentment among the masses (Ahmed, 1992; Ahmed, 2007; Hall, 1997; Said, 1981). Generalizations from individual examples in the media, or elsewhere, to wider populations lead to misunderstandings and misleading assumptions (Bhatti, 1999; Shah, 2006a), and impact negatively on the young learners' engagement who are already burdened by the demands of an intricate balancing act in a 'between cultures' context (Anwar, 1998). Across ambiguities and misconceptions, images are constructed by media and masses, which highlight the differences and increase the distances. These images convey messages of rejection and exclusion. As a reaction to 'media portrayals of Islam as barbaric, irrational, primitive and sexist' (Osler, 2003), an equally strong tendency develops to gravitate towards a concept of identity and Ummah, that are 'asserted with pride and are capable of political mobilization' (Modood, 2005). Experiences of exclusion and discrimination play a strong role in smoothing over internal differentiation leading to struggle for empowerment through a reverse discourse (Foucault, 1980), as reflected in the quote from a very young research participant: 
When others make fun of you or pass comments - you know - it makes you feel an outsider. I have been born and brought up here. I have been to Pakistan only once in my life and I don't fit there. I am walaiti [from West) there. So who do you hang around with? I used to have White friends but now all my friends are boys from our community ---Muslims. We share so many things --- and a lot to talk about.

Globalisation has fragmented many communities but new communities and association are emerging in the new world order. In spite of being target of hatred and ridicule (Parekh, 2000a; Richardson and Miles, 2003), Muslimness is becoming more visible in educational institutions. For many Muslims hijab/scarf, beards, or a dress code that can vaguely be associated with Islam has led to overt hostility (Coles, 2004, p. 41), but the number of students wearing these symbols of Muslimness is increasing. The quote from a student indicates the complexity of reasons for these choices:

Sometimes people make jokes about my scarf. I've worn it since joining secondary school --- my own choice encouraged by parents. I decided to wear it -- Quran says that scarf should be worn. ... Most of all, it is to please my parents. I'm proud to be Muslim.

Whether these symbolic gestures are Islam or not is not the point. The signals are loud and clear - 'we are Muslims'! In spite of difficult experiences, these young people persist in projecting their Muslim identity:

Comments are made about 'terrorist', 'Bin Laden' --- made by Whites about Muslim children; particularly after July. I've not experienced abuse, though I know people who have; almost every Muslim had something taken out on them; a friend with scarf at a bus stop got comments from people driving past; you feel you are being picked on. Didn't affect my connection with the school but some people did seem to look at me differently. People comment on fundamentalists, you feel they mean you because you are a Muslim. 
Another small boy complained that White boys often laughingly call him Bin Laden. 'I don't like it. ... I don't look like him, and I have no beard!' he protested. This reminds of another event quoted in Richardson and Wood:

I'm the only Asian teacher at my school. During the war in Iraq a pupil who's also Asian told me that she was being teased by other pupils. 'We killed hundreds of your lot yesterday ... Saddam's your dad, innit ... we're getting our revenge for what you Pakis did to us on 11 September...' I asked her if she had told her class teacher. Yes, she had told her teacher, and her teacher had said: 'Never mind, it's not serious. It'll soon pass. You'll have to expect a bit of teasing at a time like this.' (2004, p. 64)

What can be the educational implications of this bit of 'teasing' or 'fun'? Can this phenomenon be expected to contribute to a cohesive multi-faith, multi-cultural society? Policies are implemented in a real life context and the real life context does not appear to be very encouraging for accommodating Muslimness. This issue of Muslim identity, and its projections and perceptions impact on inclusion and educational engagement of young Muslim students in schools.

\section{Muslimness: implications for inclusion, and engagement}

The education of diverse groups of students from different cultural, religious and ethnic backgrounds has become an increasingly complex, controversial and problematic challenge across the world (Banks \& McGee Banks, 2003; Griffin, 2007, Griffiths et al, 2003, Meer, 2007, Parker-Jenkins, 2007, Shah, 2006b). An increasing number of schools in the United Kingdom (UK) are emerging as multi-ethnic, multi-cultural and multi-faith (Shah, 2006a), posing challenges of developing and sustaining inclusive policies that are sensitive and responsive to issues of ethnicity and identity (Abbas, 2005; Anwar, 1998, Brah, 1996, Feagin et al, 1996, Shah, 2006, Vincent, 2003). Although schools, especially in urban areas, are often experienced and successful in providing for diverse needs, there are long-standing concerns about the extent to which equal opportunities policy has been 
translated into effective practice (Macpherson, 1999). These concerns apply in particular to Muslim students.

Haque and Bell (2001, 366) proclaim that Muslim students in British schools, mostly comprising of poorer communities such as Bangladeshi and Pakistani groups, perform below average on public tests, and for these reasons constitute a cause for concern. Secondly, the apparent alienation of a significant number of second generation Muslims (Hardy, 2005) suggests that their sense of inclusion in British society, or lack of it, has become problematic. Under-achievement and absence of a 'sense of belonging' among the Muslims are both damaging for inclusion and engagement.

Before the setting up of the Commission on Integration and Cohesion (Woodward, 2006), policies for managing diversity and inclusion encouraged schools 'to offer a range of extended services that help pupils engage and achieve,' (DFES, 2004, pp. 1-2). The assumption was that a diverse society should agree on a set of 'shared values' that transcends 'deep-seated conflicts between cultures embodying different values' (Malik, 2002). The failure of multiculturalism and the search for "practical solutions, based on local ideas that have potential' (Singh, 2006) has shifted the focus. Now it is doubly important to understand the experiences and perspectives of Muslim students and how these may in future contribute to new forms of inclusive education.

The initiatives and strategies adopted over the last few decades to achieve inclusion in educational institutions (Doyle, 2006) have lacked full cognizance of the ethnic cultures and their value systems. This has often resulted in confusion and tensions at the implementation stage, adversely affecting the outcomes of the plans conceived with the best of intentions. The research participants in both schools acknowledged and appreciated the efforts by the schools, and school-heads in particular, to ensure inclusion and achievement. This included relevant policies, monitoring of processes and practices, appropriate use of curriculum, engaging staff from minority ethnic backgrounds, involving parents and listening to them, developing channels for communication in spite of barriers like language/culture etc, and having 'systems in place to fight racism'. These schools made positive efforts to celebrate ethnicity. One school was going to celebrate 
'Black Day' in October and the students were quite excited about it. They seemed comfortable working together but a participating teacher's comment, 'we can't enforce social mixing out in the playground', signals the limitations of the efforts.

One major complaint was that the efforts by schools at inclusion and cohesion were negatively affected by media images. The desire to 'belong to UK' is frustrated by experiences of rejection. A participating Muslim teacher who has had his schooling in the same school commented:

It seems harder to be a Muslim. I'm a Muslim, just a Muslim, not anything else. Don't know why media, TV lead me to think I'm Bangladeshi, not English. I feel rejected - generally, everything the way it's done, media, government, and policies.

Inclusionary approaches need to be positioned within a framework of equality and shared values. Media hypes and uninformed comments from responsible people can trigger off unanticipated reactions. For example, David Blunkett's (2003) criticism of young British Muslims as 'feeling part of their faith', and suggesting to speak English in their homes (2004), or Peter Hain's (2004) implied suggestion that second and third generation British Muslims are still foreigners if they maintain their religious identity raised concerns about parent culture, language and faith instead of promoting social cohesion. The message seemed to be that integration is 'at the price of ... becoming less Muslim' (Smith, 2002, p. 14) which was exclusionary, and negated the policy that 'No one should be forced to choose between being British and being Muslim' (House of Commons, 2005). A Year 8 participating girl, born and brought up in UK stated:

I don't have a sense of belonging to England - being a Muslim is the most important identity for me. I feel I belong in Bangladesh - because I'm a Bengali. I do want to belong to UK and to mix in with others, but --

And this 'but' is the challenge in working towards inclusion. It points to a gap in mutual understanding, asking for a change in approach and attitudes. The suggestion is that for inclusion policies to be effective there also needs to be a conducive environment. 


\section{Managing Muslimness}

Management of 'Muslim identity' in educational institutions has become a sensitive issue because of its implications for educational engagement and inclusion. According to Merry (2007), identity formation is a 'coherent sense of self within a particular cultural matrix' (p. 75), in spite of the fact that formulations of identity are fraught with many tensions. He argues that 'a learning environment culturally (or religiously) consonant with the parents is more likely to produce healthy learning outcomes for young children and is more likely to foster a firmer sense of self' (2007, p.78). Muslim community has been voicing concerns on diverse forums that the learning environment provided to the Muslim children is not 'culturally (or religiously) consonant with the parents'. Instead of brushing their grave concerns under the carpet, it is time to reflect and to engage with them to devise policies and practices for a better future. Educational leaders have a responsibility to create an environment where learners feel valued and respected.

Placing value and respect in individuals and groups can be more effective to encourage inclusion and engagement, than all the glossy terms and projects. Creating a coherent and cohesive environment requires positive approaches and liberal attitudes, promoting criticality and understanding. Educational leaders have a responsibility to put systems and processes in place that practically discourage marginalisation. Even a term like multiculturalism is increasingly being perceived as a buzzword, reinforcing division and marginalisation. Parekh hints at the dissatisfaction with the associated discourse when he highlights the need to separate dialogical multiculturalism 'from segregationist multiculturalism, which leads to ghettoisation, and also from hegemonic multiculturalism, which assigns minorities a fixed space' (2004).

Today's school context has moved much further from the early 1990s, when measures like language, dress, food, prayer-rooms, etc. were on top priority to facilitate schooling for the Muslim children (Parker-Jenkins, 1995). Needs now extend to demands for recognising faith as a category of difference and for making appropriate provisions - with signals that if the schools fail to recognise their needs these learners would 'go to private schools or mosques' (Smith, 2002, p. 10). The role of mosques and imams in Britain 
(Lewis, 1994) and Muslim faith schools with reference to the education of Muslim youth is gaining significance (Cush, 2005; Gardner; Meer, 2007; Merry, 2007). This has led to the emergence of Independent Islamic schools that are managed by religious and educational leaders in the local community to address the serious issues of inclusion, achievement and learners' identity. The perceived vacuum left by mainstream education has provided them a space for functioning. And their performance with reference to students' achievement at GCSEs level is justifying their existence. The state schools appear to be not doing enough to tackle racism, to promote race relations (Parker-Jenkins, 2005) and to improve achievement as compared to Independent Islamic schools (Gardener et al, 2005; Lawson, 2005; Meer, 2007).

According to 2006 National league tables for England and Wales Independent Islamic schools, in spite of meagre resources, have excelled as compared to multicultural state schools located in the same social and economic areas. Two Independent Islamic schools in Birmingham and Hackney achieved 100\% A-C grades in five or more GCSEs (Ahmad, 2002). Many Independent Islamic schools, commonly known as faith schools, seem to have addressed the Muslim learner's needs for academic achievement in recent times, with seven independent schools becoming state maintained (Special Report, 2006). Several studies acknowledge that Muslim learners achieve much higher scores in Independent Islamic schools (Lawson, 2005; Meer, 2007). Furthermore, these schools seem to prepare students better for integration through developing a confidence in personal identity (Hewer, 2001; Lawson, 2005; Merry, 2007; Parker-Jenkins, 2005).

Islamic schools do face the challenges of integrating Muslim learners into the mainstream social and economic system of British culture by managing the balance between requirements for Muslim learners' socio-cultural values and state pressures for social inclusion and achievement. However, they seem to be doing well in meeting these challenges (Lawson, 2005; Merry, 2007). In this backdrop, underachievement of Muslim students in the mainstream state schools raises questions regarding the factors that cause Muslim underachievement in the state schools. This emphasises the need to investigate the barriers to Muslim students' achievement, and to explore the areas in which mainstream schools are un-successful to provide appropriate support to Muslim learners. 
An understanding of these issues has profound implications for educational leaders working towards a common agenda for inclusion and achievement in a multicultural state system with regard to Muslim learners' identity who may feel marginalised or misunderstood. This requires informed awareness of improved leadership role when working with Muslim learners to understand their cultural values to further support social inclusion, achievement and learners' identity (Merry, 2007). Perhaps working closely with Independent or/and State Maintained Islamic schools can be another way forward to enhance understanding of issues, and knowledge of how to manage these issues.

Another important role of leaders is to prepare teachers to be sensitive to religious and religion-related cultural differences. Many teachers working in the British state system are unaware of racist attitudes amongst pupils (Richardson and Wood, 2004). They have a responsibility not only to deal with racist incidents but also to prepare pupils for life in a multicultural and multiracial society and to improve their own knowledge and understanding of the communities of students they are responsible for (Parker-Jenkins, 2005; Coles, 2004). As majority of Muslims continue to be educated in non-Muslim state schools, it is important that the government and the schools make practical decisions to ensure accommodation of religious needs. An improved understanding of Islam and Muslim values among staff, governors, and school community in general can enhance mutual accommodation of needs and tolerance. Ameli et al (2005) recommend better teacher training on diversity, and a greater balance of perspectives within the curriculum aiming at generating dialogue through the national curriculum.

The educational leaders, including both the policy makers and practitioners, might deprive the future society of its huge potential if they fail to fulfil their responsibilities to ensure inclusion and engagement of Muslim students or any other group. Lee Jasper, senior advisor to the London Mayor on Race Relations, pointed to this phenomenon many years back, and it invites serious thought even today:

Islands of exclusion imprison within them boundless talent and creativity, confined by sheer walls of discrimination and lack of opportunity. People will 
inevitably cleave tightly to the central tenets of their culture and faith. Occasionally when provoked they will react like a cornered tiger. (2001, Online)

The new generation of British-born Muslims, in particular, sees itself as equal partners in national membership - not marginalised immigrants. Self-identity, as Giddens argues, is 'the self as reflexively understood by the person in terms of her or his biography (original italics)' (1993, p. 53). 'We are, not what we are, but what we make of ourselves' (Giddens, 1993, p. 75). The issue is no longer to which group these students have been born but the right to equality as British citizens with multiple identities. The resistance to the dominant educational discourse is not a rejection of education - this would not align with the Islamic philosophy (Shah, 2006b) - but a challenge to the existing power relations, seeking not just toleration for ethnic difference but 'expecting others to respect them and adapt public attitudes and arrangements so that the heritage they represent is encouraged rather than contemptuously expected to whither away' (Modood et al, 1997, p. 358). It is time to consider the thought provoking question put forward by Esposito:

Can the majority of Muslims retain both their faith and their identities and do so in a manner that enables them to also accept and function within the secular, pluralistic traditions of Europe and America? (2002, p. viii)

Managing diversity is a great challenge posed by changing societal demographics. Bauman (2002) suggests to find new ways to reforge the human diversity into human solidarity. In the case of Muslims, this requires a change in attitudes towards the new sociological 'other' - Muslimness. Literature emphasises that Muslims are not withdrawing but are being driven into Muslimness as an alternate identity because of experiences of alienation and marginalisation in the wider society (Hopkins and KahaniHopkins, 2004; Kepel, 2003; Modood, 2004). Some major complaints from Muslims as highlighted by literature (Richardson, 2004; Parekh, 2000) and confirmed by this study include lack of respect for their faith, prophet, rituals and way of life, religious discrimination in all fields of life, experiences of Islamophobia, and hostility from media and masses. These experiences affect young students in and outside the schools, as well as their families and communities. Within the collective Muslim community, issues from 
'out-group' are experienced and responded collectively, contributing to 'in-group' identity formations. In spite of huge inner diversity of Muslim Ummah (Shah, 2006b) and vast variations in personal levels of adherement to Islamic practices, faith retains a unique status for Muslims:

For many Muslims, Islam is the key determinant in their lives. Yet schools are not always sensitive to this. Pupils, as they enter through the school portals, are required to leave their religion at home, not through design but because so often the school as a secular institution, is simply unaware of the centrality of Islam in the life of its Muslim pupils. (Coles, 2004, p. 43)

It is only when individuals from all religious, ethnic and other orientations are acknowledged as equally valued, 'fellow citizens', that the issue of students' achievement can be considered in proper perspective. It would be too simplistic to expect 'others' not to realise the difference between being manipulated for reasons, or being the focus of genuine care as equal citizens - being a window dressing or valued partners (Rubin, 2002). An inclusive school should make schooling a positive experience for all the students. Admittedly, every school context is a unique context, but a wider knowledge base of those responsible for schooling can nevertheless enhance understanding.

School leaders in multiethnic societies certainly need to cultivate commonalities for all practical purposes and for social cohesion, but the need is also to be sensitive to ethnic and faith difference, developing 'a respect for persons as individuals and for the collectivities, to which people have a sense of belonging' (Modood et al, 1997, p. 359). A pride and confidence in their heritage contributes to the learners' enhanced performance, and it is the teachers' and leaders' task to facilitate that goal by respecting diversity, by enhancing the students' confidence in identity and by strengthening the notion of equality in relationships.

In addition to that, getting to know students and communities, and soliciting comprehensive involvement and collaboration is another important factor contributing towards the learners' educational engagement and achievement. The schools need to aim 
for 'culturally coherent education' (Michael, 2005) which should encourage and value hybrid identities, which may not necessarily be conflictual. An appreciation of students' self-perceptions 'may assist minority children in countering the negative stereotypes and discrimination they face in the larger society' (Michael, 2005, p. 1). In the case of Muslim students, faith emerges as a significant factor in their identity formations, and therefore recognising its role and significance should underpin future policies regarding education and inclusion.

\section{$\underline{\text { References }}$}

Abbas, T. (2004) The Education of British South Asians: Ethnicity, Capital and Class Structure; London and New York: Palgrave.

Abbas, T. (2006) Muslims in Birmingham, UK. Background paper for the University of Oxford Centre on Migration Policy and Society.

Abbas, T. (ed) 2005, Muslim Britain: communities under pressure. London: Zed Books.

Afridi, S. (2001) Muslims in America: Identity, Diversity and the Challenge of Understanding. Carnegie Challenge: Carnegie Corp. New York, NY.

Ahmad, I (2006) State Funded Muslim Schools

http://www.standards.dfes.gov.uk/forums/showflat.php?Cat=\&Number=3023\&page= $\underline{0 \& \text { view }=\text { collapsed } \& \mathrm{sb}=5 \& \mathrm{o}=\& \mathrm{fpart}=1}$

Ahmad, I. (2002) The Needs of Muslim Children can be Met Only Through Muslim Schools' Wednesday May 22, 2002 http://society.guardian.co.uk/publicvoices/education/story/0,,720049,00.html 
Ahmed, A. S. (1992) Post-Modernism and Islam: Predicament and Promise. London, Routledge.

Ahmed, A. S. (2003) Islam Under Siege: living dangerously in a post-honor world. Cambridge, UK: Polity Press.

Ahmed, S. T. (2003a) Young British Muslims: social space and active identity. PhD Thesis. University of Leicester.

Ahmed, S. T. (2003b) Young Muslims and Muslim Media in Britain. Conference Paper presented at EMTEL Conference, 23-26 April 2003, London School of Economics, London Accessed on 28.02.07 http://www.lse.ac.uk/collections/EMTEL/Conference/papers/Ahmed.doc

Ahmed, S. T. (2007) Media stereotype good/bad Muslims. Online http://www.theasiannews.co.uk/news/s/223/223898_media_stereotype_goodbad_mus lims_html

Al-Ahsan, A. (1992) Ummah or Nation: Identity Crisis in Contemporary Muslim society. The Islamic Foundation: Liecester.

Alles, E. (2003) 'Muslim Religious Education in China', in China Perspectives, January February 2003, pp 21 to 29

Ameli, S. R., Azam, A. and Merali, A. (2005) Secular or Islamic? What Schools do British Muslims want for their Children? (VOL. 3 of the British Muslims' Expectations Series, summary). Publication date: 6th of July 2005 http://ihrc.org.uk/file/BMEG_VOL3.pdf

Anwar, M and Bakhsh, Q. (2002) State Policies Towards Muslims In Britain; A Research Report. Centre for Research in Ethnic Relations; University of Warwick.

Anwar, M. (1998) Between cultures: continuity and change in the lives of young Asians. London: Routledge. 
Archer, Louise. (2003) Race, Masculinity and Schooling: Muslim boys and education. Open University Press.

Bagguley, P. and Hussain, Y. (2007) The Role of Higher Education in Providing Opportunities for South Asian Women. University of Leeds, Published in association with Joseph Rowntree Foundation.

Banks, J.A., \& McGee Banks, C.A. (eds) 2003, Handbook of Research on Multicultural Education. San Francisco: Jossey-Bass.

Basit, T. (1997) Eastern values, western milieu : identities and aspirations of adolescent British Muslim girls. Aldershot: Ashgate.

Bauman, Z. (2002) Society Under Siege. Cambridge: Polity Press in association with Blackwell Publishers.

BBC (2005) Police Shot Brazilian Eight Times. 25 July, 2005; Retrieved on 15.08.2007. http://news.bbc.co.uk/1/hi/uk/4713753.stm

BBC 2006 "No charges for Forest Gate victim" (HTML), BBC News, 2006-10-27. Retrieved on 15.08.2007. http://news.bbc.co.uk/1/hi/england/6092624.stm

Bhabha, H. (1994) The Location Of Culture. London: Routledge.

Bhatti, G. (1999) Asian Children at Home and at School. London: Routledge.

Blunkett, D. (2003) Home Secretary, David Blunkett's controversial Speech in York on October 30, 2003.

Blunkett, D. (2004) Rethinking Britishness, Foreign Policy Centre. UK.

Brah, A. (1996) Cartographies of Diaspora: contesting identities. London: Routledge. 
Brasted, H.V. (2005) 'Islam and Identity in South Asia: at the crossroads of confusion and confrotation', in Johns, A. H, and Lahoud, N. (eds) Islam in World Politics. London, Routledge.

Chiang, L. H. (2001) Education of Chinese Muslims: Changes in the 20th Century. AACS 2001 Annual Conference. US; Indiana.

Coles, M. I. (2004) Education and Islam: a new strategic approach. Race Equality Teaching, Vol. 22, Summer 2004, pp. 41-46. Trentham Books

CRE (2005) Citizenship and Belonging: what is Britishnes? ETHNOS Research and Consultancy by the Commission for Racial Equality (CRE) in 2005. online http://www.cre.gov.uk/downloads/what_is_britishness.pdf

Cush, D, (2005) The Faith Schools Debate. British Journal of Sociology of Education; 26(3) July 2005, pp. 435-442.

DfES, (2004) National Curriculum Assessment and GCSE/GNVQ Attainment by Pupil Characteristics in England , 2002 (Final) and 2003 (Provisional). London: DES; available online, www.dfes.gov.uk/rsgateway/DB/SFR/

Djao, Wei (2004) 'Being Chinese: Voices from the Diaspora'. The Social Science Journal, 41(2) 323-325.

Doyle, A. (2006) 'Educational Equality, Religion and the Education of Muslim Pupils: a comparative study of France and England' in R. Griffin (ed) Education in the Muslim World: different perspectives. Symposium Books.

Driel, B. van (ed) 2004, Confronting Islamophobia in Educational Practice. Trentham Books.

Esposito, J. L. (1999) The Islamic Threat: myth or reality? $3^{\text {rd }}$ edition. Oxford : Oxford University Press. 
Esposito, J. L. (2002) Unholy War: terror in the name of Islam. Oxford: Oxford University Press.

Feagin, J., Vera, H. and Imani, N. (1996) The Agony of Education: black students at white colleges and universities. New York; London: Routledge.

Foucault, M. (1980) Power/Knowledge: Selected Interviews and Other Writings, (19721977). Brighton: Harvester Press.

Gardner, R.; Cairns, J. and Lawton, D. (eds) 2005, Faith Schools: consensus or conflict? London, Routledge Falmer.

Giddens, A. (1993) Sociology, 2nd rev. ed. Cambridge: Polity Press.

Griffin, R (ed) 2007, Education in the Muslim World: Different Perspectives. Symposium Books.

Griffiths, M. and Troyna, B. (eds) 1995, Antiracism, culture and social justice in education. Stoke-on-Trent: Trentham Books.

Griffiths, M. et al (2003) Action for social justice in education: fairly different. Open University Press.

Haddad, Y. (ed.) 2002, Muslims in the West: from sojourners to citizens. Oxford University Press.

Hagopian, E. C. (2004) Civil Rights in Peril-The Targeting of Arabs and Muslims. Haymarket Books, Chicago.

Hain, P. (2004) Minister of Europe, Peter Hain's Interview with Sunday Times, May 9, 2004.

Hall, S. (1992) 'New Ethnicities', in A. Rattansi and J. Donald (eds.) Race, Culture and Difference. Sage Publications; pp. 252-259. 
Hall, S. (1996) 'Introduction: Who Needs Identity?', in S. Hall, and P. de Gay (ed.s) Questions of Cultural Identity, London, Sage; pp. 1-17.

Hall, S. (ed.) 1997, Representation: Cultural Representations and Signifying Practices. London, Sage.

Haque, Z. (2000) 'The Ethnic Minority 'Underachieving' Group? Investigating the Claims of 'Underachievement' amongst Bangladeshi Pupils in British Secondary Schools'. Race, Ethnicity and Education; 3(2) 145-168.

Haque, Z. and Bell, J. F. (2001) 'Evaluating the Performance of Minority Ethnic Pupils in Secondary Schools'. Oxford Review of Education; 27(3) 358-368.

Hardy, R. (2005) 'UK Multiculturalism under Spotlight', 14 July 2005, at www.news.bbc.co.uk/1/hi/uk/4681615.stm.

Hewer, C. (2001) 'Schools for Muslims'. Oxford Review of Education; 27(4), pp. 515527.

Hopkins, N. and Kahani-Hopkins, V. (2004) The Antecedents of Identification: A Rhetorical Analysis of British Muslims Activists' Constructions of Community and Identity', in British Journal of Social Psychology, 43(1), pp.41-57.

House of Commons (2005) Select Committee on Home Affairs Sixth Report http://www.publications.parliament.uk/pa/cm200405/cmselect/cmhaff/165/16510.htm

Hussain, Y. and Bagguley, P. (2005) Citizenship, Ethnicity and Identity: British Pakistanis after the 2001 'Riots'. Sociology, 39(3), pp.407-425.

Jacobson, J. (1998) Islam in transition: religion and identity among British Pakistani youth. London: Routledge.

Jasper, L. (2001) Brickbats for Oldham, The Guardian, 29 May 2001. Online http://www.guardian.co.uk/racism/Story/0,497888,00.html. 
Kabbani, R. (2002) Dislocation and neglect in Muslim Britain's ghettos. Monday June 17, 2002. The Guardian.

Kepel, G. (1997) Allah in the West: Islamic movements in America and Europe. Oxford: Polity Press.

Kepel, G. (2003) Jihad: the trial of political Islam. London: I. B. Tauris.

Le Breton, J. M. (1999) Muslims in France and Britain; Report of a seminar held at the Weston European Union, Paris, 17-18 November 1998. London: Franco-British Council.

Lewis, P. (1994) Islamic Britain: religion, politics and identity among British Muslims. London : I.B. Tauris.

Limage, L. J. (2000) Education and Muslim Identity: the case of France. Comparative Education (36)1, pp. 73-94.

Macpherson, W. (1999) The Stephen Lawrence Inquiry: report of an inquiry. London: TSO.

Malik, K (2002) Debates online 'can multiculturalism work?' http://www.kenanmalik.com/lectures/multiculturalism_if.html

Mandaville, P. (2001) Transnational Muslim Politics: Reimagining the Umma. London: Routledge.

MCB (2007) Towards Greater Understanding: Meeting the needs of Muslim pupils in state schools'. Online http://www.mcb.org.uk/downloads/Schoolinfoguidancev2.pdf

Meer, N. (2007) 'Muslim Schools in Britain: challenging mobilisations or logical developments'. Asia Pacific Journal of Education. 27(1) March 2007, pp55-71.

Michael, S. M. (2005) 'Cultural Coherence and the Schooling for Identity Maintenance'. Journal of Philosophy of Education, 39 (3), 477-497. 
Modood, T. (2003) 'Ethnic differences in educational performance', in Mason, D (ed) Explaining Ethnic Differences: changing patterns of disadvantage in Britian; Policy Press, Bristol.

Modood, T. (2004) 'Britishness out of Immigration and Anti-Racism', in H. Brocklehurst and R. Phillips (eds.) History, Nationhood and the Question of Britain; pp.85-98 Basingstoke: Palgrave.

Modood, T. (2005) Ethnicity and Intergenerational Identities and Adaptations in Britain: The Socio-Political Context in Rutter, M. \& Tienda, M. (eds.) Ethnicity and causal mechanisms; pp.281-300; New York \& Cambridge: Cambridge University Press.

Modood, T., Berthoud, R., Lakey, J., Nazroo, J., Smith, P., Virdee, S. and Beishon, S. (1997) Ethnic minorities in Britain: diversity and disadvantage. London: Policy Studies Institute.

MPA (2004) A report by the Metropolitan Police Authority. BBC News World Edition. (http://news.bbc.co.uk/2/hi/uk_news/england/london/3732169.stm. Last Updated: Thursday, 20 May, 2004, 17:08 GMT 18:08 UK.

National Statistics (2001) Online Office for National Statistics http://www.statistics.gov.uk.

O’Leary, Z. (2005) Researching real-world problems: A guide to methods of Inquiry, Sage Publications, London.

Osler, A. (2003) Muslim women teachers: life histories, identities and citizenship in: T. Benn and H. Jawad (Eds.) Muslim Women in the United Kingdom and Beyond: Experiences and Images Women and Gender: The Middle East and the Islamic World, 2. Netherlands: Brill.

Parekh, B. (2000) The future of multi-ethnic Britain : report of the Commission on the Future of Multi-Ethnic Britain. Runnymede Trust. London. 
Parekh, B. (2000a) Rethinking multiculturalism : cultural diversity and political theory. Basingstoke : Palgrave.

Parekh, B. (2004) We're All British, But We Speak In Different Accents. Speech at the launch of the Centre for Research on Nationalism, Ethnicity and Multiculturalism, June 11, 2004.

Parker-Jenkins, M. (1995) Children of Islam: a teacher's guide to meeting the needs of Muslim pupils. Stoke-on-Trent: Trentham.

Parker-Jenkins, M. (2007) Aiming High. Sage Publications.

Parker-Jenkins, M., Hartas, D. and Irving, Barrie A. (2005) In good faith: schools, religion, and public funding. Ashgate.

Richardson, R. (2004) Islamophobia: issues, challenges and action. Trentham Books Limited.

Richardson, R. and Miles, B. (2003) Equality stories: recognition, respect and raising achievement : schools and local education authorities in multi-ethnic Britain. Stokeon-Trent : Trentham.

Richardson, R. and Wood, A. (2004) The Achievement of British Pakistani Learners; WORK IN PROGRESS. The report of the RAISE project, 2002-04, funded by Yorkshire Forward. Trentham Books.

Rubin, H. (2002) Collaborative leadership: developing effective partnerships in communities and schools. Thousand Oaks, Calif.: Corwin Press

Said, E. W. (1981) Covering Islam: How the Media and the Experts Determine How We See the Rest of the World. London: Routledge and Kegan Paul

Sen, A. (2006) Identity and violence : the illusion of destiny. London : Allen Lane. 
Shah, S. (2006) 'Ethnicity, Identity and Religious Values: what are the implications for both religious and community schools?' Keynote Symposium at British Educational Research Association Annual Conference 2006, $6^{\text {th }}-9^{\text {th }}$ September.

Shah, S. (2006a) 'Leading Multiethnic Schools: a new understanding of Muslim Youth Identity'. Journal of Educational Management, Administration and Leadership; Special Edition on Leadership and Diversity; April 2006; 34(2) 215-237.

Shah, S. (2006b) 'Educational Leadership: an Islamic perspective'. British Educational Research Journal, 32(3)363-385.

Singh, D. (2006), Speech by Darra Singh, Chair of the Commission on Integration and Cohesion (CIC) at the launch of the Commission on 24 August 2006. http://www.communities.gov.uk/index.asp?id=1502287

Smith, J. I. (2002) 'Introduction’ to Y. Haddad (ed.) op. cit.

Special Report (2006) State and Religion. Published: 10 September 2006 Online http://education.independent.co.uk/news/article1433332.ece.

Tlemçani, R. (1997) Islam in France: The French Have Themselves to Blame. The Middle East Quarterly; IV(1).

Tyrer, D. and Ahmad, F. (2006) Muslim Women and Higher Education: Identities, Experiences and Prospects; A Summary Report. Oxuniprint, Oxford. Online http://image.guardian.co.uk/sysfiles/Education/documents/2006/08/02/muslimwomen.pdf

Vertovec, S. (2002) ‘Islamophobia and Muslim recognition in Britain', in Y. Haddad (ed.) op. cit.

Vincent, C. (ed.) 2003, Social justice, education, and identity. London: Routledge Falmer. 
Werbner, P. (1997) 'Essentialising Essentialism, Essentialising Silence: Ambivalence and Multiplicity in the Constructions of Racism and Ethnicity', in P. Werbner and T. Modood (eds.), Debating Cultural Hybridity: multi-cultural identities and the politics of anti-racism; London: Zed Books; pp. 226-254.

Werbner, P. (2000) 'Divided Loyalties, Empowered Citizenship? Muslims in Britian'. Citizenship Studies, 4(3), pp. 307-324.

Woodward, W. (2006) 'Kelly vows that new debate on immigration will engage critically with multiculturalism', The Guardian, 25 August 2006.

\footnotetext{
${ }^{\mathrm{i}}$ Undoubtedly, this approach has serious limitations as for example, Indians are a high achieving group and about $20 \%$ of Indians are Muslims (http://en.wikipedia.org/wiki/Religion_in_India\#Demographics). In the absence of data being collected by faith, Muslims of Indian origin become excluded from generalisation regarding achievement of Muslim learners.

ii There are sixty-four occurrences of the term in the Quran (Al-Ahsan 1992), where it is used as an overarching concept for wider Muslim community operative beyond geo-political bounds. Commonly, this term is used among Muslims to convey the fact that Muslims the world over constitute one Ummah or community.
} 